\title{
The masters of thoracic trauma in the Central Hospital of the Mexican Red Cross. Their story and legacy
}

\author{
Juan Carlos Vázquez-Minero', Guillermo Vallejo-Sandoval, Anette Ochmann-Ratch', \\ Laura Portillo-Téllez and Demian Trueba-Lozano ${ }^{4}$ \\ ${ }^{1}$ General and cardiothoracic surgeon; ${ }^{2} \mathrm{Head}$ of the Department of General Surgery and Emergency; ${ }^{3}$ Medical director; ${ }^{4}$ Department of General
} Surgery. Hospital Central de la Cruz Roja Mexicana, Mexico City, Mexico

\begin{abstract}
The branches of medicine responsible for the care of victims of different types of injuries were born as a result of the urgent need to save lives during the wars. In Mexico, one of the first hospitals developed for the care of injured patients was the Central Hospital of the Mexican Red Cross. The aim of this article is to pay tribute to the first service for the care of patients with chest trauma, founded in 1954, its founders and those who have continued with their work: Dr. Pedro Garza Alegría, Dr. Octavio Rivas Solís Dr. Jesús Genis Becerra, etc. In 64 years of existence, there have been trained eight specialists in cardiothoracic surgery and three of them have worked in the Central Hospital of the Mexican Red Cross.
\end{abstract}

KEY WORDS: Cardiothoracic surgery. Trauma. Red Cross.

\section{History of trauma care-specialized hospitals}

In 1847, as the US army was getting close to Mexico City, the local city council founded two hospital centers for the care of victims of the imminent conflict. These hospitals were built at the San Lázaro gate and the San Pablo convent, and started looking after the wounded of the Padierna and Churubusco battles since August 23 of that year'.

Subsequently, shortfalls in the care of patients with injuries resulting from accidents and aggressions in the city led to the need to create specialized places for their immediate care. For this reason, Leopoldo Castro created the first first-aid post in the street of Revillagigedo, in 1908. This space had instruments to carry out emergency surgery and resources for the transportation of patients. This fact marked the initiation of the Green Cross ${ }^{1,2}$.

\section{History of the Mexican Red Cross}

The history of the Mexican Red Cross goes back to 1906, when General Porfirio Díaz signed the agreement by means of which Mexico joined the $1864 \mathrm{Ge}$ neva Convention, with the purpose to improve the care of the wounded and the sick of armies on campaign. Two years later, on June 5, 1909, the first board of directors of the Mexican Red Cross was installed.

The first help brigade that carried the banner of the Red Cross departed from Mexico City in 1909 to assist the victims of a flood that affected Monterrey. This brigade was led by Mrs. Luz González Cosío de López and Dr. Fernando López y Sánchez Román.

In 1910, the Mexican Red Cross -which in its statutes was named Mexican Association of the Red Cross- was officially recognized; this decree was published in the Official Journal of the Federation on March 12 of that year, and on April 26, the first board

\section{Correspondence:}

Juan Carlos Vázquez-Minero

Avenida Ejército Nacional, 1032

Col. Los Morales/Polanco

Date of reception: 16-07-2016

C.P. 11510, Ciudad de México, México

E-mail: minerojc@hotmail.com
Date of acceptance: 21-04-2017

DOI://dx.doi.org/10.24875/GMM.M18000060
Gac Med Mex. 2017;153:661-664

Contents available at PubMed www.gacetamedicademexico.com 
of directors was founded. In 1911, the International Committee of the Red Cross granted recognition to the Mexican Red Cross and, in 1923, it was recognized by the League of Red Cross and Red Crescent Societies.

The first ambulance services, as well as first aid assistance to the victims of revolutionary combats, were provided in Mexico City,3.

\section{History of the Red Cross hospitals}

The creation of facilities to provide patient care occurred as follows:

- 1909-1910: 19 Artes Str. (Antonio Caso).

- 1910-1914: 20 Rosales Str. (Caballito Tower).

- 1914-1916: 40 Paseo de la Reforma Av. (next to the Federal District Chamber of Commerce); San Francisco and National Theater (Central Av. and Madero Str.), Guardiola Building (former Escandón Building).

- 1916-1934: 14 San Jerónimo Str. (Concepción Béistegui or Regina or San Jerónimo Hospital).

- 1934-1968: Durango and Monterrey Str. (Roma area).

- 1968 until the present day: 1032 Ejército Nacional Av., Los Morales/Polanco area (Central Hospital).

This last hospital location is closely linked to the National Headquarters facilities (Mexican Red Cross National Directive Entity, which was hosted for a long time within the hospital itself). The National Headquarters are located at 200 Juan Vives Street, and the Federal District Delegation at 1032 Ejército Nacional Av. This is where the arrangements needed for the foundation of the then called Mexican Association of the Red Cross were carried out, and where the first helping actions provided by the institution were organized and coordinated ${ }^{3,4}$.

\section{Trauma-associated thoracic surgery history}

The oldest reference on the management of thoracic trauma in America is probably the narration Alvar Núñez Cabeza de Vaca made about the extraction of an arrow lodged in the chest of an indigenous American ${ }^{5}$. There are very few subsequent reports until 1902, when Dr. Adrián de Garay described heart-penetrating wounds. Next, in 1913, Dr. Javier Ibarra reported and attempt to repair a heart injury with poor results and, later, at Hospital Juárez, Doctors Rafael Vargas Otero, Clemente Robles Castillo, Fernando
Valdés Villarreal and Manuel Godoy carried out the first successful cardiac sutures ${ }^{6}$.

Until 1870, mortality of penetrating chest trauma without heart or large vessels involvement, with expectant management, was 68\%; however, between 1870 and 1898, when the first thoracentesis, pleurostomy and lavage procedures were performed, it went down to $20-30 \%$, and since 1898 , with minor vessels ligation, it dropped down to $7 \% \%^{7,8}$. This important mortality reduction demonstrated that opportune and specialized management of patients with this kind of injuries was necessary, which prompted the need to create more hospitals with personnel trained for these purposes.

\section{The Mexican Red Cross department of thoracic trauma}

Since its foundation, the Mexican Red Cross has provided treatment to patients with chest trauma. This type of care was provided by general surgeons until the arrival of Dr. Pedro Alegría Garza, a military doctor graduated in 1946 who worked at the Huipulco Hospital for Tuberculosis Patients (currently the National Institute of Respiratory Diseases) as pulmonologist and thoracic surgeon.

Dr. Alegría came to work at the old Monterrey and Durango hospital, which was founded in 1954, together with Doctors Pablo Cruz Esparza (general surgeon and gastroenterologist), Edmundo Ángeles and Gloria Eugenia Torres (pulmonologist), also coming from the Huipulco Tuberculosis Patients Hospital, and founded the first department of thoracic surgery for emergency cases in a hospital, by invitation of the Honorable Medical Committee of the Red Cross, given the need of specialized care for these patients ${ }^{9}$.

The Mexican Red Cross new Hospital was founded on January 16, 1968 at 10:30 hours by the president of the Republic Gustavo Díaz Ordaz, with Mr. José Barroso Chávez being appointed as chairman of the institution. In these new facilities, the thoracic trauma department work continued with Dr. Octavio Rivas Solís in charge, since Dr. Pedro Alegría Torres was assigned as teaching coordinator ${ }^{10}$.

Dr. Jesús Genis Becerra, native to Mexico City and National Autonomous University of Mexico 1956 graduate -although he initiated his medical studies at the Military Medical School- studied the pulmonology and thoracic surgery specialties at the Institute of Pulmonology and Thoracic Surgery (currently Hospital General Manuel Gea González) from 1958 to 1961. In 1954, 
during his undergraduate stage, he carried out his emergency medicine practices at the Red Cross Hospital, where he got in touch with the thoracic traumatology specialized department and his appreciation for thoracic surgery was born. After having worked at the Mexican Institute of Social Security as a pulmonologist in 1971, he returned to the Red Cross Hospital, where he was hired as thoracic surgery specialist and worked for one year with Dr. Pedro Alegría, sharing responsibilities such as patient care, placing and looking after pleurostomy tubes, using two-bottle water-seal systems and practicing thoracotomies in patients acutely requiring it or for the resolution of complications ${ }^{11}$.

Dr. Alegría worked for one more year and retired in 1972 with 18 years of service at the Red Cross. Dr. Octavio Rivas Solís, who was a cardiovascular surgeon graduated from the Instituto Nacional de Cardiología Ignacio Chávez, worked for the Mexican Red Cross at its Monterrey and Durango streets former headquarters, and continued for a few years in the new Polanco hospital, looking after patients with thoracic and cardiovascular trauma until 1972, when he decided to dedicate full-time to sport psychology, a subject he has been a mentor of to the present day. As of that year, Dr. Genis remained in charge of the department of thoracic trauma until 2008, when he retired after 36 years of service in the institution.

These three pillars of Mexican thoracic surgery not only devoted their valuable time and dedication to the founding of a department and the care of patients, but also opened a breeding ground for new generations.

\section{New generations}

Hospitals play a fundamental role for societies, since they are centers for the care and solution of problems, places of research and venues for the training of new specialists. General surgeons are trained at the Red Cross Central Hospital. The training period used to be 3 years until the year of 2000, after which the National Autonomous University of Mexico increased it to 4 years. At the conclusion of their training, doctors -many of them from the hinterland and some other foreigners- leave to enter the working field; however, some look for further training. Close contact with the thoracic trauma pathology contributed to start the training of the first cardiothoracic surgery specialist, who had been trained as general surgeon at the Mexican Red Cross.

As a consequence of the interest of great surgeons who were dedicated to thoracic trauma, appreciation for the area arose in new generations, out of which eight additional surgeons have graduated so far, all of them trained at the Centro Médico Nacional (CMN) 20 de Noviembre, of the Institute for Social Security and Services for State Workers (ISSSTE - Instituto de Seguridad y Servicios Sociales de los Trabajadores del Estado), after concluding their training in general surgery, with 3 or 4-year periods. Below, a list presented with their names, the period when they specialized in cardiothoracic surgery, and the place where they currently work, exalting the names of the Red Cross and the 20 de Noviembre Hospital:

- Dr. Joaquín Rodolfo Zepeda Sanabria, 19901993 (CMN 20 de Noviembre and Siglo XXI UMAE Pediatrics Hospital).

- Dr. Francisco Rueda Ríos, 1992-1995 (Tijuana ISSSTE Hospital).

- Dr. Hugo García Aranda, 1994-1997 (General Hospital of Zacatecas).

- Dr. Alma Angélica del Rocío Jiménez Godínez, 1995-1998 (Hospital Ángeles de Tijuana).

- Dra. María del Sol García Ortegón, 19982002(CMN 20 de Noviembre).

- Dr. Jorge Villela Caleti, 1999-2003 (PEMEX South Hospital).

- Dr. Juan Carlos Vázquez Minero, 2001-2005 (INER and DF Red Cross).

- Dr. Manuel Fernando Rodríguez Ortega,20032007 (ISSEMYM Medical Center).

Of these subspecialists, many migrated to their places of origin, but three of them have worked at different stages in the Red Cross Central Hospital, continuing the noble work of the thoracic trauma department founders: Dr. Joaquín Rodolfo Zepeda Sanabria (1992-2006) at shift A, Dr. Jorge Villela Caleti (2002-2004) at shift A, and Dr. Juan Carlos Vázquez Minero (2005 to this day), responsible of the department at the afternoon shift since 2008.

Sixty-two years have elapsed since the project of Dr. Pedro Alegría and his group was initiated, and thousands of patients with thoracic traumatic pathology have been treated, looking to improve their care, decrease complications deriving from their injuries and teach general surgeons thoracic trauma pathology adequate management.

\section{The department of thoracic trauma at present}

The success of this department, where the cardiothoracic surgeon acts as the head, lies in the 
participation of all shift chiefs of staff and staff physicians of the general surgery department different shifts, together with the general surgery resident, who -during their shifts- carry out specific diagnoses, surgical interventions and specialized medical emergency management related to countless traumatic pathologies involving the chest, such as pulmonary, cardiac, diaphragmatic, esophageal, vascular and chest wall injuries, performing procedures such as urgency and emergency thoracotomies, as well as chest drains placement and care, minimizing more serious complications, such as retained hemothorax and posttraumatic empyema.

The above-mentioned procedures have been performed throughout the 62 years of life of the department. It is impossible for all names to be mentioned, but it is true that each and every one of them have contributed with their grain of sand to the strengthening of the department and the teaching of the opportune management of the patient with chest traumatic pathology. Currently, there is a cardiothoracic surgery specialist who, together with general surgeons and residents, carries out the care of the patient with thoracic trauma.

\section{Conclusions}

Although it is true that there are no specialists in the area at all shifts, general surgeons of the institution are capable to resolve acute and emergency pathology to give way to specific postoperative management and follow-up of patients by the physician in charge of the department since its foundation. This way, outpatient care has been maintained for 62 uninterrupted years, in order to take care of hospital-discharged patients follow-up.
In our country, there are very few thoracic surgery specialists dedicated to the care of trauma patients; however, at the Mexican Red Cross Central Hospital there is a department that fulfills this fundamental mission since 62 years ago. Care has been provided to patients with pulmonary, cardiac, tracheal, diaphragmatic, esophageal and large vessel injuries; complications such as coagulated hemothorax, posttraumatic empyema and bronchopleural fistula have been resolved, and patients with tracheal stenosis, bronchial ruptures, aorta dissections and posttraumatic heart failure have been referred to specialized centers.

This work is not only accomplished by cardiothoracic surgery specialists, but it also implies the participation of general surgeons and residents who work shoulder to shoulder for the wellbeing of patients. To all of them, thanks.

\section{References}

1. Carreón BR, Rodríguez PA. El inicio del manejo del traumatismo en la Ciudad de México. Gac Med Mex. 2005;141:161-3.

2. Rodríguez PA, Carreón BR. Cronología del manejo quirúrgico del trauma en México (900 A.C.-1917). Resumen histórico del trauma. Trauma. 2005;8:10-3.

3. Cruz Roja Mexicana. Una obra de mexicanos en beneficio de Ta humanidad. 85 años de la historia de la Cruz Roja Mexicana. México, D.F.: Cruz Roja Mexicana; 1995.

4. Cruz Roja Mexicana. 100 años gracias a ti. México, D.F.: Gustavo Casasola Ediciones; 2010.

5. Munguía CD, Ibarra PC, Rodríguez PM. Pioneros de la cirugía torácica mexicana. Gac Med Mex. 2011;147:342-9.

6. Alcántara HJ. Compendio de cronología quirúrgica mexicana. Cir Cir. 1951;19:1-21, 163-91.

7. Villagrán BJ. Apuntes sobre las heridas penetrantes de pecho complicadas de hematotórax, casos en los que está indicada la toracocentesis y ventajas de este tratamiento. Gac Med Mex. 1864;8:121-5.

8. Soriano MS. Estadística quirúrgica de las heridas penetrantes de tórax o vientre. Gac Med Mex. 1898;35:274-8.

9. Garza PA. Traumatología del tórax. México, D.F.: La Prensa Mexicana; 1962. p. VII-X.

10. Cruz Roja Mexicana. Libro de oro de la Cruz Roja. Edición conmemorativa. México, D.F.: Cruz Roja Mexicana; 1968

11. Genis J. Testimonio. Trauma. 2006:9:5. 